\title{
The effect of the land use on phytoplankton assemblages of a Cerrado stream (Brazil)
}

\author{
Os efeitos do uso do solo sobre as assembleias fitoplanctônicas de um riacho \\ de Cerrado (Brasil)
}

\section{Mateus Ferrareze}

Departamento de Zoologia, Instituto de Biociências, Universidade Estadual Paulista - UNESP, CP 510, CEP 18618-000, Botucatu, SP, Brazil

e-mail: mferrareze@ibb.unesp.br

\begin{abstract}
Aim: Our aim was to investigate whether land use from the adjacent terrestrial environment influences phytoplankton assemblage structure (composition, richness, diversity, and abundance) and biomass (chlorophyll- $a$ ) in a Cerrado stream during different periods of the year. Method: The fieldwork was carried out at each 3 months during two years. Results: The physical and chemical variables that better indicated differences in water condition were conductivity, dissolved oxygen, and transparency. There was also a noticeable increase in the concentration of nitrogen, phosphorus, and suspended matter in the water during summer due to the direct effects of rainfall. The phytoplankton assemblages were composed by 64 species. Cryptophyceae was the most abundant group, followed by Bacillariophyceae. For both years, richness and diversity were higher during spring and autumn, while phytoplankton abundance and chlorophyll- $a$ concentration were greater during autumn and summer. The cluster and the canonic correspondence analyses evidenced that seasonality and land use are important factors in structuring phytoplankton communities along the year. Alterations in phytoplankton assemblages registered herein were probably a consequence of variations on intensity and frequency of water mixing, along with the input of nutrients from the adjacent terrestrial system. Conclusion: Overall phytoplankton assemblage structure showed to be highly influenced by land use, corroborating our initial hypothesis.
\end{abstract}

Keywords: algae, lotic system, diversity, abundance and human influence.

Resumo: Objetivo: Nosso objetivo foi investigar se o uso do solo do ambiente terrestre adjacente influencia a estrutura das assembleias fitoplanctônicas (composição, riqueza, diversidade e abundância) e biomassa (clorofila- $a$ ) em um riacho de Cerrado durante diferentes períodos do ano. Métodos: Os trabalhos de campo foram realizados trimestralmente durante dois anos. Resultados: As variáveis físico-químicas que melhor indicaram as diferenças nas condiçóes da água foram condutividade, oxigênio dissolvido e transparência. Também houve um notável aumento na concentração de nitrogênio, fósforo e material em suspensão na água durante o verão devido aos efeitos da pluviosidade. As assembleias fitoplanctônicas foram compostas por 64 espécies. Cryptophyceae foi o grupo mais abundante, seguido por Bacillariophyceae. Para ambos os anos, a riqueza e a diversidade foram maiores durante a primavera e no outono, enquanto que a abundância do fitoplâncton e a concentraçáo de clorofila- $a$ foram mais elevados durante o outono e verão. A análise de agrupamento e a analise de correspondência canônica mostraram que a sazonalidade e o uso do solo são fatores importantes na estruturação das assembleias ao longo do ano. As alteraçóes nas assembleias fitoplanctônicas ocorreram provavelmente em função da variação na intensidade e freqüência da mistura da água e da entrada de nutrientes oriundo do sistema terrestre adjacente para o aquático. Conclusáo: A estrutura das assembleias fitoplanctônicas mostrou ser altamente influenciada pelo uso do solo, corroborando com a hipótese inicial do trabalho.

Palavras-chave: alga, sistemas lóticos, diversidade, abundância e influência antrópica. 


\section{Introduction}

The Brazilian Savanna ecosystem, also referred to as Cerrado, occupies an area of nearly 2 million $\mathrm{km}^{2}$ and contains a high biodiversity (Mendonça et al., 1998). Despite its importance, it has been undervalued in terms of conservation. Only $0.5 \%$ of its total area is protected by restricted use conservation units (Bruck et al., 1995) and 3.6\% is protected by any category of protected conservation area (Dias, 1990). Myers et al. (2000) considered the Cerrado as one of the 25 threatened Earth ecosystems with high biodiversity.

Nearly $67 \%$ of the Brazilian Cerrado vegetation is considered as highly modified by human action and only $20 \%$ of the original state still remains (Mitermeyer et al., 1999). However, the Brazilian Constitution did not consider the Cerrado as a priority area for conservation and current changes suggested by the Executive in the Forest Code and adopted by the National Council of environment (CONAMA), enhance the possibilities of its degradation.

The accelerated Cerrado habitat losses are overwhelming and that only emphasizes the need of knowledge about the remaining fragments of this biome in order to support environmental programs and conservation strategies. On this matter, a lot of studies were conducted about the terrestrial floristic composition, though the aquatic flora continues poorly understood, especially in the Northwest region of Sao Paulo State. Among the several assemblages of aquatic flora, the most important group is the phytoplankton.

Phytoplankton plays an important role in rivers primary productivity and certain assemblages are also considered good indicators of environmental conditions (e.g. hydrodynamics and trophic state) (Rosén, 1981; Vincent and Dryden, 1989, Sommer, 1984; Reynolds, 1992, 1999; Padisák et al., 1999). The structure of algae assemblages, determined by indicators such as specific composition, cellular density, species richness, and uniformity, can be used to evaluate aquatic system quality, while specific diversity measurements can constitute an appropriate index to compare environment conditions (Rosa et al., 1988).

Phytoplankton assemblages compose the basis of the aquatic trophic chain and, consequently, human alterations in aquatic environments can promote changes in community structure and dynamics of these producers, as well as the in other trophic levels (Odum, 2004).
In this context, the present study was conducted under the hypothesis that land use from the adjacent terrestrial environment influences phytoplankton assemblages through changes on stream water conditions by human activities. Therefore, our aim was to investigate whether land use from the adjacent terrestrial environment influences phytoplankton assemblage structure (composition, richness, diversity, and abundance) and biomass (chlorophyll-a) in a Cerrado stream during different periods of the year, providing an important contribution to knowledge regarding this group.

\section{Material and Methods}

\subsection{Study area}

Fieldwork was conducted in a Colono Stream stretch, located in the Avanhadava municipality, Northwestern São Paulo State. The studied stretch is a fourth order stream and is at approximately $1.5 \mathrm{~km}$ from the stream mouth into the Pato River, in the hydrographic basin of Promissão Reservoir. The terrestrial surrounding area presents a typical Cerrado soil, deficient in nutrients and rich in iron and aluminum. It shelters plants characterized by a dry appearance among scattered bushes, grasses and herbaceous vegetation.

Land use at the hydrographic basin was mainly for livestock grazing, though recent changes to sugarcane plantations are broad. Climatological variables, obtained from the Center for Integrated Agrometeorological Information (http://www. ciiagro.sp.gov.br/ consulted on October $29^{\text {th }} 2011$ ), indicated that the average monthly rainfall and temperature during the sampling period were, respectively: summer, $52.7 \mathrm{~mm}$ and $25.3{ }^{\circ} \mathrm{C}$; autumn, $15.8 \mathrm{~mm}$ and $21.4^{\circ} \mathrm{C}$; winter, $6.7 \mathrm{~mm}$ and $21.2^{\circ} \mathrm{C}$; and spring, $32 \mathrm{~mm}$ and $24.8^{\circ} \mathrm{C}$.

\subsection{Sampling and analysis}

The fieldwork was carried out at a stretch of Colono Stream (21 $1^{\circ} 35^{\prime} 22.31^{\prime \prime} S$ and $50^{\circ} 00^{\prime} 59.5^{\prime}$ W; Figure 1), where phytoplankton assemblages were sampled in 8 expeditions (at each 3 months) from January/2003 to December/2004.

For phytoplankton quantitative analysis, unfiltered samples were collected at the subsurface (ca. $0.5 \mathrm{~m}$ ). The samples were fixed and preserved with Lugol solution. After sedimentation (Margalef, 1983), the organisms (cell, colony, and filament) were counted using inverted microscopy (sensu Uthermöhl, 1958) at a magnification of $400 \times$. At least 120 optical fields distributed in parallel 


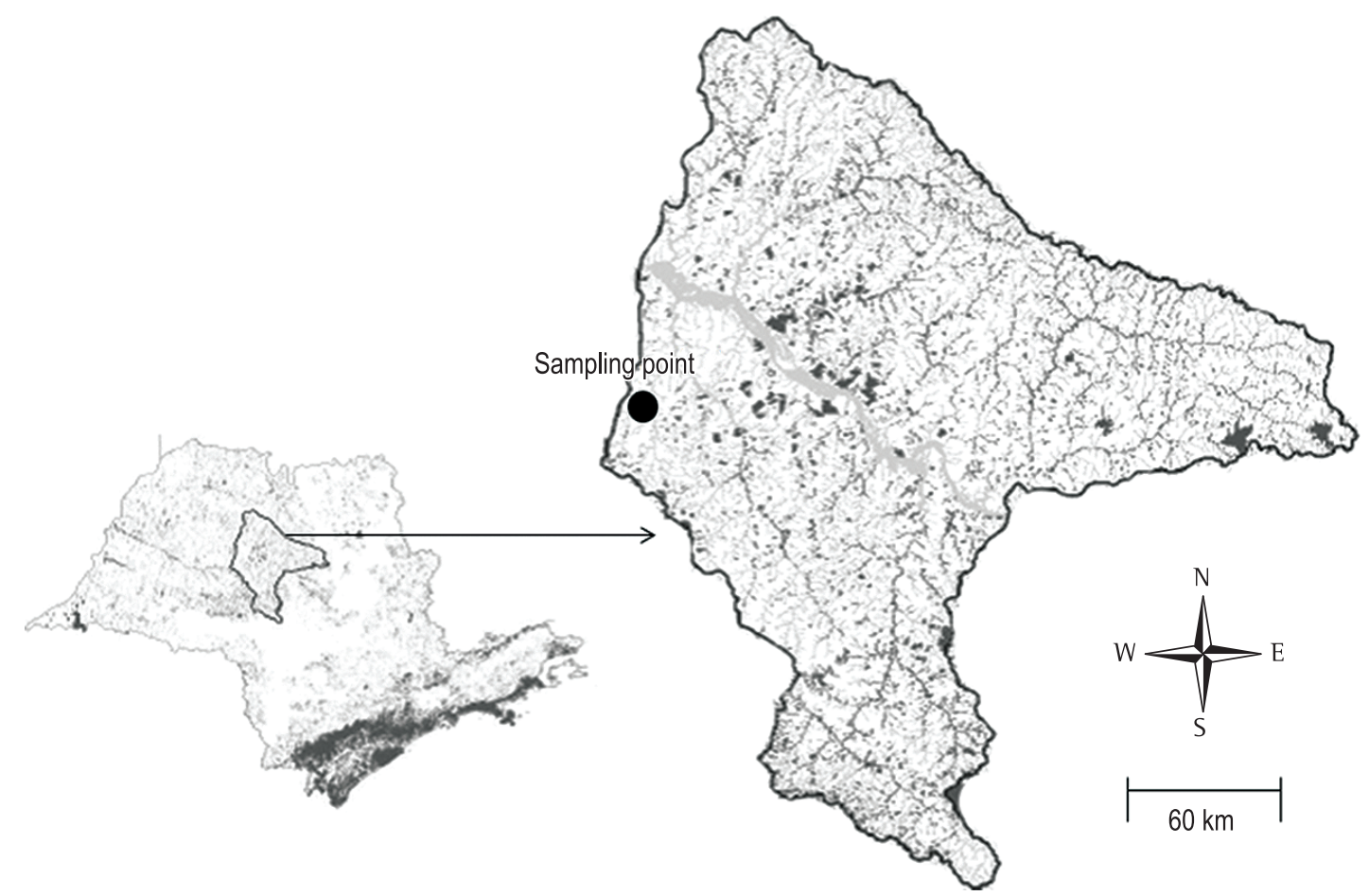

Figure 1. São Paulo State (left) and detail of the sampling point location (right).

transects were examined and the minimum of 150 individuals per sample was counted.

Filtered samples were also collected through vertical and horizontal net hauls $(20 \mu \mathrm{m}$ of mesh size) and preserved in $4 \%$ formalin. These samples were analyzed under optical microscope (maximum magnification of $1000 \times$ ) for phytoplankton identification (Bicudo and Menezes, 2005). New taxa that appeared during the quantitative analyzes were also considered for a qualitative purpose (list of taxa).

As an index of phytoplankton biomass, chlorophyll- $a$ (total) concentration was determined. One liter of water from each sampling depth was filtered. (Millipore AP40 membranes) For pigment extraction, it was used cold acetone $(90 \%)$ and manual maceration (Talling and Driver, 1963; Golterman et al., 1978).

Phytoplankton diversity was estimated using the Shannon-Weaver Index $(\log 2)$. In order to compare phytoplankton assemblage structure among sampling sites a cluster analysis ( $\mathrm{r}$-Pearson similarity) (Pcordwin) was performed using the abundance per class.

Temperature, dissolved oxygen, conductivity, and $\mathrm{pH}$ were measured in situ using the water analyzer Horiba (mod. U-22). Transparency was measured by using a Secchi disk. The suspended matter was determined by gravimetry (Cole, 1979) and total nitrogenous and total phosphorus were determined by the methods of Mackereth et al. (1978) and Strickland and Parsons (1960), respectively. The correlation between abiotic and biotic variables was determined by the canonic correspondence analyses, CCA (Pcordwin). All data were previously standardized $\left(\log _{x+1}\right)$, except the $\mathrm{pH}$.

Finally, a One-way ANOVA was applied in order to show temporal differences among phytoplankton assemblages. When differences were detected, the Tukey test was applied to determine the level of significance $(\mathrm{p}<0.05)$. Previously, data normality and homoscedasticity was assessed using Shapiro-Wilk and Levene tests, respectively. Analysis of variance and the statistical tests were performed using Statistica TM 8.0 software (Statsoft, 2001).

\section{Results}

The limnological variables (Table 1 ) that better indicated differences in water quality were conductivity, dissolved oxygen, and transparency. The highest electric conductivity was measured during summer $(\mathrm{p}=0.001)$. The lowest oxygen concentration was found during the autumn $(p=0.002)$, and the lowest transparency was observed during summer $(\mathrm{p}=0.0001)$. There was also a noticeable increase in the concentration of 
nitrogen, phosphorus, and suspended solids in the water during summer $(\mathrm{p}=0.001)$ due to direct rainfall. The concentration of suspended solids in summer was about eight times higher than in winter.

The phytoplankton assemblages were composed by 64 species. Chlorophyceae was the most specious group (20 taxa), followed by Bacillariophyceae (17 taxa), Cyanophyceae (10 taxa), Euglenophyceae (6 taxa), Zygnemaphyceae (4 taxa), Chrysophyceae (4 taxa), Cryptophyceae (2 taxa), and Dinophyceae (1 taxa).

Richness pattern along the year was similar for both years. The highest values were found during autumn and spring and the lowest values during winter and summer (Figure 2; $\mathrm{p}=0.002$ ).

In general, a tendency of increase in phytoplankton abundance was observed in the phytoplankton from winter to autumn. The highest values occurred in autumn and summer, while the lowest values was observed in winter and spring (Figure 3; p =0.001). The same pattern was registered for phytoplankton biomass (chlorophyll-a) (Figure 4; $\mathrm{p}=0.02$ ).

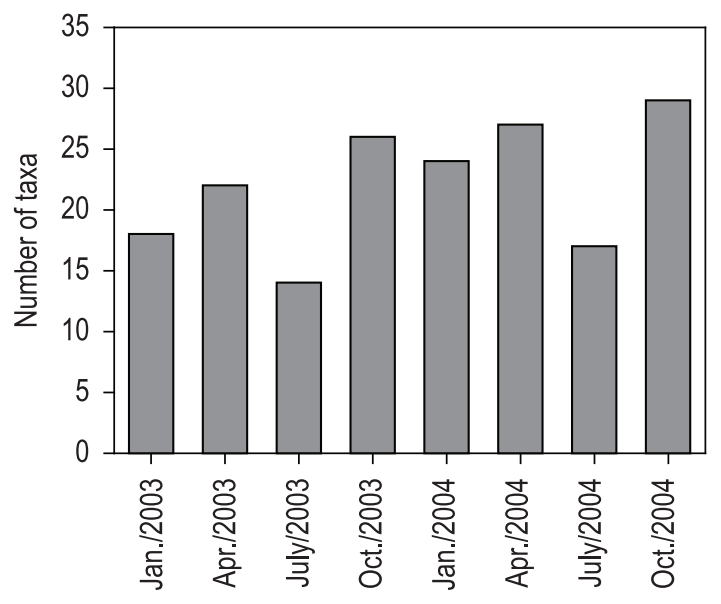

Figure 2. Total number of phytoplankton taxa sampled during different periods of the year at Colono River.
With regards to relative abundance (Table 1), the green algae were not numerically dominant despite the higher number of species. Cryptophyceae was the most abundant group (55.9\%), followed by Bacillariophyceae (19.6\%). Cryptophyceae exhibited the highest dominance during all periods of the year. A conspicuous and homogeneous presence of Bacillariophyceae occurred during the sampling periods. Chlorophyceae had a relatively higher contribution only in autumn and spring of 2004, when the species Monoraphidium contortum (Thur. ex Bréb.) Kom.-Legner had a high density. Cyanophyceae and Euglenophyceae had lower density in all periods.

The main taxa, in terms of abundance and distribution, were Discotella stelligera (Cleve and Grunow) Houk and Klee among the Bacillariophyceae; $M$. contortum among the Chlorophyceae; Lepocinclis acus (O.F. Mül.) B. Marin

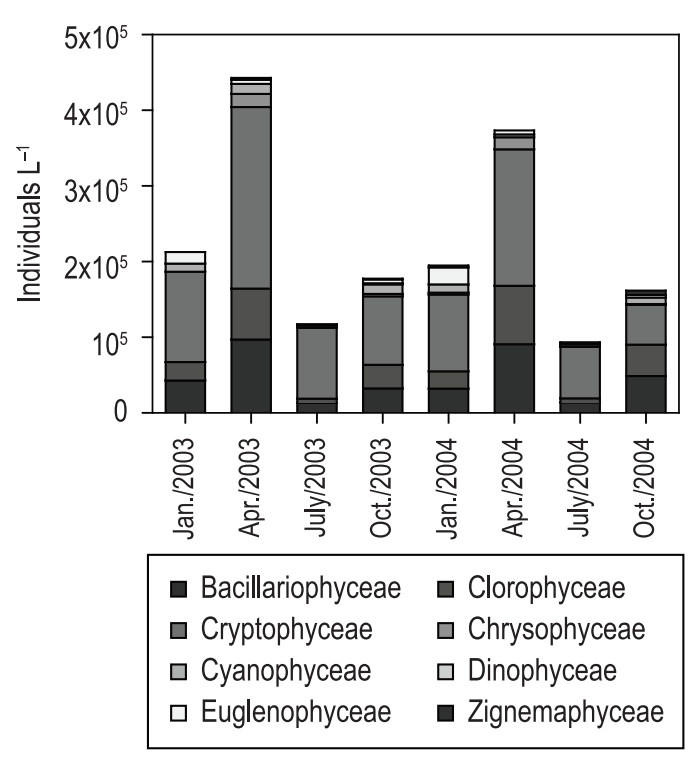

Figure 3. Abundance of phytoplankton assemblages sampled during different periods of the year at Colono River.

Table 1. Values of the limnological variables measured during different periods of the year at Colono River.

\begin{tabular}{|c|c|c|c|c|c|c|c|c|}
\hline & Jan./03 & Apr./03 & July/03 & Oct./03 & Jan/.04 & Apr./04 & July/04 & Oct./04 \\
\hline $\mathrm{pH}$ & 6.2 & 6.6 & 7.3 & 7.1 & 6.3 & 6.6 & 7.3 & 7.6 \\
\hline Conductivity $\left(\mu \mathrm{S} . \mathrm{cm}^{-1}\right)$ & 85 & 80 & 44 & 64 & 80 & 70 & 40 & 52 \\
\hline Dissolved oxygen (mg. $\left.\mathrm{L}^{-1}\right)$ & 6.3 & 5.0 & 9.5 & 8.3 & 5.9 & 5.2 & 10.0 & 9.0 \\
\hline Temperature $\left({ }^{\circ} \mathrm{C}\right)$ & 27.2 & 27.6 & 25.4 & 22.2 & 27.0 & 27.3 & 25.2 & 22.5 \\
\hline Suspended matter $\left(\mathrm{mg} \cdot \mathrm{L}^{-1}\right)$ & 18.4 & 9.3 & 2.7 & 2.0 & 16.0 & 8.6 & 2.0 & 2.4 \\
\hline Transparency (m) & 0.1 & 0.5 & 2.1 & $3.5^{*}$ & 0.2 & 1 & 2.5 & $3.5^{\star}$ \\
\hline Total phosphorus $\left(\mu \mathrm{g} \cdot \mathrm{L}^{-1}\right)$ & 53.8 & 45.6 & 30.4 & 26.0 & 49.0 & 38.4 & 28.7 & 24.2 \\
\hline Total nitrogen $\left(\mu \mathrm{g} . \mathrm{L}^{-1}\right)$ & 533 & 321 & 241 & 252 & 555 & 364 & 306 & 289 \\
\hline
\end{tabular}

* = botton. 
and Melkonian among the Euglenophyceae; Pseudanabaena mucicola (Naumann and Huber-PeStalozzi) Bourrelly associated with Microcystis aeruginosa (Kützing) Kützing among the Cyanophyceae; and Cryptomonas brasiliensis Castro, Bicudo and Bicudo among the Cryptophyceae.

The highest phytoplankton diversity, for both years, was recorded in spring and autumn, as also observed for richness. The lowest values were observed in winter and summer (Figure 5; $\mathrm{p}=0.0003)$.

Cluster analysis (Figure 6) evidenced the same pattern of phytoplankton assemblage structure between both years. The best correlated group was winter, due to the highest dominance of Cryptophyceae. Summer periods were clustered, due to the highest contribution of Euglenophyceae observed in this period for both years. Autumn/2004 remained isolated due to the lowest dominance of Cryptophyceae and the most homogeneous distribution of organisms among the phytoplankton classes.

The canonic correspondence analyses (Figure 7) explained $67.8 \%$ of data variance in the two first axes $(\mathrm{p}<0.01)$. The scores showed a clear separation among sampling periods. In winter, samplings were correlated with higher values of dissolved oxygen and transparency and lower values of conductivity. In summer, samplings were associated with higher values of temperature, total nitrogenous and phosphorus and suspended matter. Autumn and spring were at an intermediate position between summer and winter due to the amplitude of limnological variables. The values of biotic scores of Crysophyceae, Dinophyceae,

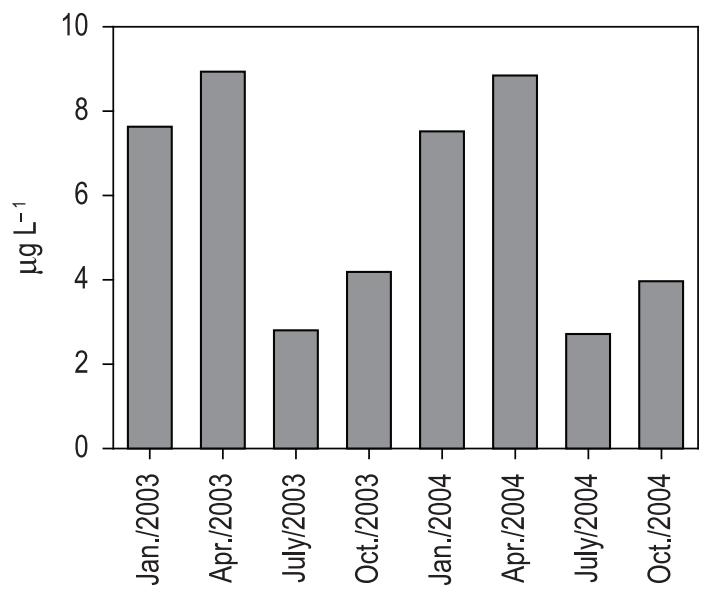

Figure 4. Chlorophyll- $a$ concentrations sampled during different periods of the year at Colono River. and Zygnemaphyceae were not significant, though Chlorophyceae showed to be correlated with autumn and spring. Cyanophyceae were associated with spring, while Cryptophyceae, Euglenophyceae and Bacillariophyceae were related to summer periods.

\section{Discussion}

Phytoplankton assemblages showed great seasonal changes during the two years. Variations in composition, abundance, and biomass were highly influenced by the land use, such as plant breeding, fertilizer, and pesticides (Ferrareze and Nogueira, 2006).

In the study site, the predominant land use is for sugarcane crops, for which the use of fertilizes is recommended during two periods of the year, firstly during the autumn and afterwards during spring (Raij et al., 1996). During these periods, the phytoplankton assemblages studied herein presented the highest growing and diversity. Part of the nutrients available in fertilizers is probably carried to the stream, becoming an important nutritive resource for aquatic producers such as phytoplankton. Nutrient inputs to the aquatic system favor phytoplankton growth, reproduction and diversity, even in a small lotic environment like a stream.

Other important factor is the burning process associated to sugarcane harvesting from early of May, during the driest months. The lowest values in phytoplankton abundance were observed in July for both years, a pattern which is probably influenced by the harvesting process.

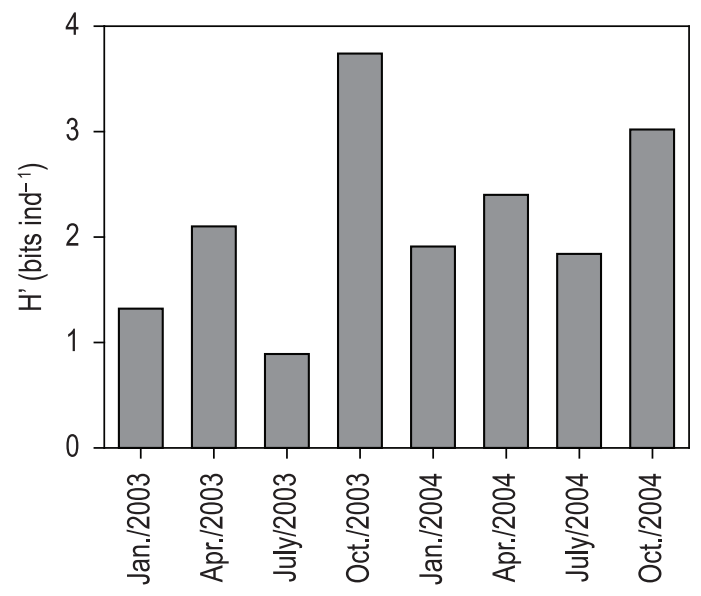

Figure 5. Shannon-Weaver diversity of phytoplankton assemblage sampled during different periods of the year at Colono River. 


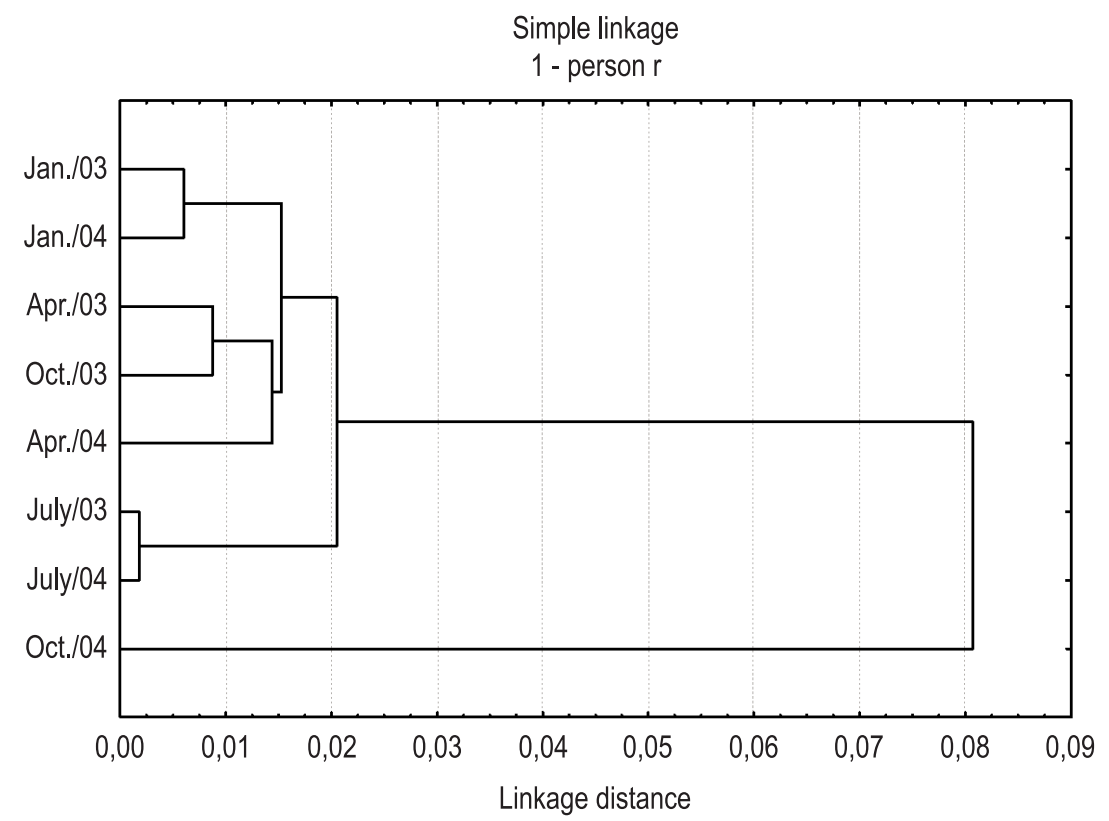

Figure 6. Similarity analysis of sampling periods, considering the abundance of phytoplankton classes.

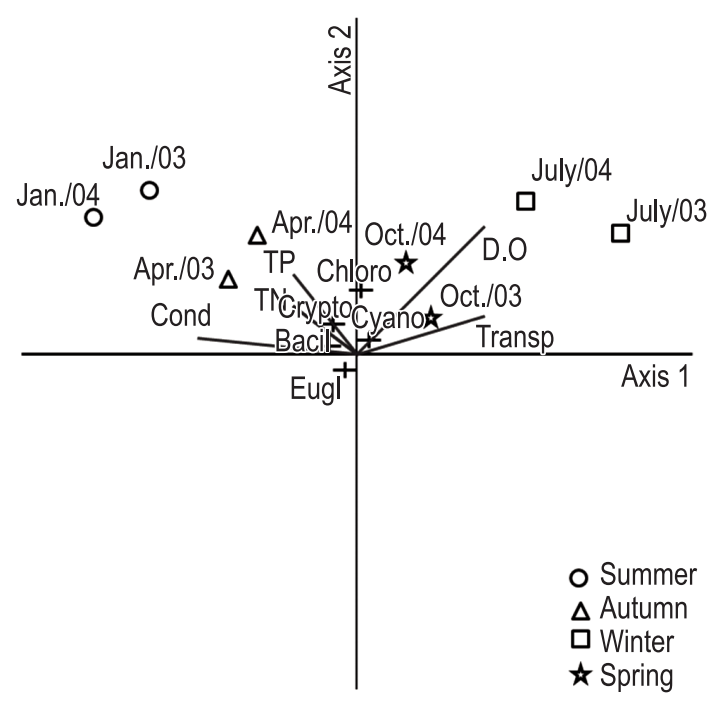

Figure 7. Canonical correspondence analysis (CCA) showing the distribution of phytoplankton classes in relation to the limnological variables, where, Chloro = Chlorophyceae; Cyano = Cyanophyceae; Crypto $=$ Cryptophyceae; Bacil = Bacillariophyceae; Eugl = Euglenophyceae; Transp = transparency; D. $\mathrm{O}=$ Dissolved oxygen; $\mathrm{TP}=$ Total phosphorus; $\mathrm{TN}=$ Total nitrogen; and Cond $=$ Conductivity

Still, meteorological factors like precipitation and temperature also had influence on phytoplankton assemblages, corroborating the findings of other studies (Santos and Calijuri, 1998; Nogueira, 2000; Gomes and Miranda, 2001; Calijuri et al., 2002; Matsumura-Tundisi and Tundisi, 2005). Additionally, richness, absolute abundance, and chlorophyll- $a$ variations evidenced that these assemblages responded quickly to the environmental variations (Reynolds, 1984).

In this study, Chlorophyceae was the most specious phytoplankton group, followed by Bacillaryophyceae. This structural characteristic seems to be a consistent pattern for phytoplankton assemblages in lotic systems. High richness of Chlorophyceae and Bacillaryophyceae have also been observed by Nogueira (2000) for a lotic compartment of Jurumirim Reservoir; by Bittencourt-Oliveira (2002) for the Tibagi River; and by Ferrareze and Nogueira (2006) for lotic stretches of the Paranapanema River and tributaries.

High values were probably observed as a function of the instability of water column (lotic system) and the input of nutrients from the soil use, leading to a community with predominance of r-strategist species like Cryptomonas, or of C-strategists as Discotella and Monoraphidium, species which are typical of the initial phase of succession (Reynolds, 1984).

Positive correlation among phytoplankton assemblages and nutrient concentration and water mixing was observed in the upper Paraná River by Train and Rodrigues (1998), Branco and Senna (1996) and Santos and Rocha (1998), studying reservoir and urban streams, respectively. As consequence of the abundance enhancement, a high concentration of chlorophyll- $a$ was observed, indicating these assemblages responded quickly to the environmental variations (Reynolds, 1984). 
Water column instability and nutrient inputs could explain the low ecological alterations among phytoplankton assemblages during the studied period. These conditions are not propitious for most phytoplankton species (Reynolds, 1984). This scenario allowed the Cryptophyeae (r-strategist) to be dominant during all periods. Only during few periods, some species were able to grow, such as the increase of Monoraphidium and Discotella abundance observed during autumn and spring.

Monoraphidium is an opportunist species, dominating in turbulent environments with a high availability of nutrients and light (Calijuri et al., 2002). Generally, Monoraphidium abundance coincides with that of the small diatoms, though it reaches its peak immediately after the peak of the diatoms (Happey-Wood, 1988).

Discotella is dominant in oligotrophic environments with great availability of light and a low Si:P ratio, if compared to other diatoms, such as those of the group of Pennales (Reynolds, 1984; Sommer, 1988). The diatoms occur during periods with high nutrient availability and good light conditions and they grow quickly, especially in the presence of high nitrogen concentration, being opportunists and colonizers ( $\mathrm{r}$-strategists and C-strategists) (Reynolds, 1984; Sommer, 1988).

The low abundance of Cyanophyceae was expected, since they are usually abundant only in environments with a more stable water column (S-strategists, according to Reynolds, 1996), a condition that is less common in small streams (Calijuri and Santos, 1996). The increase of Euglenophyceae during the summer is probably due to the higher inputs of organic matter, carried from the terrestrial system by rainfall, typical of this period, to the aquatic system.

The cluster analysis and the canonical analysis showed that the seasonality is an important factor in structuring phytoplankton assemblages, though it is not the exclusive main force. Land use at adjacent areas probably provides an important nutrient load, leading some species to grow, reproduce and diversify, restructuring the phytoplankton assemblage as a whole (Ferrareze and Nogueira, 2006).

Finally, it is important to stress the necessity to consider the role that streams play for large hydrographic basins, along with associated biotic communities. Despite generally being considered of minor importance in terms of water volume, small and medium-sized tributaries present phytoplankton assemblages that can influence water quality conditions in large rivers. Since these streams come from different regional areas with particular urban and agricultural characteristics, they can actually contribute with significant loads and organisms entrance into large rivers or reservoirs (Henry et al., 1999; Moretto and Nogueira, 2003; Pinto-Coelho et al., 2005; Ferrareze and Nogueira, 2006).

\section{Acknowledgements}

The author is grateful to Duke Energy, particularly to Norberto Castro Vianna, for laboratory availability and fieldwork materials, and to Raoul Henry for the constructive comments during the manuscript preparation.

\section{References}

BICUDO, CEM. and MENEZES, M. 2005. Gêneros de algas de águas continentais do Brasil: chave para identificação e descrições. Rima: São Carlos. 489 p.

BITTENCOURT-OLIVEIRA, MC. 2002. A comunidade fitoplanctônica do Rio Tibagi: uma abordagem preliminar de sua diversidade. In MEDRI, ME., BIANCHINI, E., SHIBATTA OA. and PIMENTA, JA., eds. A bacia do rio Tibagi. Londrina: M.E. Medri. cap. 21, p. 373-402.

BRANCO, CWC. and SENNA, AC. 1996. Phytoplankton composition, community strture and seasonal changes in a tropical reservoir (Paranoá Reservoir, Brazil). Algological Studies, vol. 81:69-84.

BRUCK, EC., FREIRE, MV. and LIMA, MF. 1995. Unidades de conservação no Brasil, cadastramento e vegetação 1991-1994. Brasília: IBAMA.

CALIJURI, MC. and SANTOS ACA. 1996. Short term changes in the Barra Bonita reservoir (São Paulo, Brazil): emphasis on the phytoplankton communities. Hydrobiologia, vol. 330, p. 163-175. http://dx.doi.org/10.1007/BF00024205

CALIJURI, MC., SANTOS, ACA. and JATI, S. 2002. Temporal changes in the phytoplankton community structure in a tropical and eutrophic reservoir (Barra Bonita, SP-Brazil). Journal of Plankton Research, vol. 24, p. 617-634. http://dx.doi.org/10.1093/ plankt/24.7.617

COLE, GA. 1979. Textbook of limnology. 2nd. ed. Saint Louis: The C.V. Mosby Company. 426 p.

DIAS, BFS. 1990. A conservação da natureza. In NOVAES PINTO, M., org. Cerrado: caracterização, ocupação e perspectivas. Brasília: Editora Universidade de Brasília. p. 583-640.

FERRAREZE, M. and NOGUEIRA, MG. 2006. Phytoplankton assemblages in lotic systems of the Paranapanema Basin (Southeast Brazil). Acta Limnologica Brasiliensia, vol. 18, no. 4, p. 389-405. 
GOLTERMAN, HL., CLYMO, RS. and OHSTAD, MA. 1978. Methods for physical and chemical analysis of fresh waters. 2nd. ed. Oxford: Blackweel Scientific Publications. 213 p.

GOMES, LC. and MIRANDA, LE. 2001. Hydrologic and climatic regimes limit phytoplankton biomass in reservoirs of the Upper Paraná River Basin, Brazil. Hydrobiologia, vol. 457, p. 205-214.

HAPPEY-WOOD, CM. 1988. Ecology of freshwater planktonic green algae. In SANDGREN, CD., ed. Growth and reproductive strategies of freshwater phytoplankton. Cambridge: Cambridge University Press. p. 175-226.

HENRY, R., SANTOS, AAN. and CAMARGO, YR. 1999. Transporte de sólidos suspensos, $\mathrm{N}$ e $\mathrm{P}$ total pelos Rios Paranapanema e Taquari e uma avaliação de sua exportação na represa de Jurumirim. In HENRY, R., ed. Ecologia de reservatórios: Estrutura, função e aspectos sociais. Botucatu: FAPESP/ FUNDIBIO. p. 687-710.

MACKERETH, FJH., HERON, J. and TALLING, FJ. 1978. Water analysis: some revised methods for limnologists. Freshwater Biological Association. Kendall: Titus Wilson \& Sons Ltd. 120 p. Scientific Publication, no. 36.

MARGALEF, R. 1983. Limnologia. Barcelona: Omega S.A. 1010 p.

MATSUMURA-TUNDISI, T. and TUNDISI, JG. 2005. Plankton richness in a eutrophic reservoir (Barra Bonita Reservoir, SP, Brazil). Hydrobiologia, vol. 542, p. 367-378. http://dx.doi.org/10.1007/ s10750-004-9461-0

MENDONÇA, RC., FELFILI, JM., WALTER, BMT., SILVA JÚNIOR, MC., REZENDE, AV., FILGUEIRAS, TS. and NOGUEIRA, PE. 1998. Flora vascular do cerrado. In ALMEIDA, SP., ed. Cerrado: ambiente e flora. Planaltina: EmbrapaCPAC. p. 287- 556.

MITERMEYER, RA., MYERS, N. and MITERMEYER, CG. 1999. Earth's biologically richest and most endangered terrestrial ecoregions. Mexico City: CEMEX- Conservation International. 430 p.

MORETTO, EM. and NOGUEIRA, MG. 2003. Physical and chemical characteristics of Lavapés and Capivara Rivers, tributaries of Barra Bonita Reservoir (São Paulo - Brazil). Acta Limnologica. Brasiliensia, vol.15, no. 1, p. 27-39.

MYERS, N., MITTERMEIER, RA., MITTERMEIER, CG., FONSECA, GAB. and KENT, J. 2000. Biodiversity hotspots for conservation priorities. Nature, vol. 403, no. 6772, p. 853-858. PMid:10706275. http://dx.doi.org/10.1038/35002501

NOGUEIRA, MG. 2000. Phytoplankton composition, dominance and abundance as indicators of enviromental compartmentalization in Jurumirim Reservoir (Paranapanema River), São Paulo, Brazil.
Hydrobiologia, vol. 431, p. 115-128. http://dx.doi. org/10.1023/A:1003769408757

ODUM, EP. 2004. Fundamentals of Ecology. 5th ed. Brooks Cole. 624 p.

PADISÁK, J., KÖHLER, J. and HOEG, S. 1999. The effect of changing flushing rates on development of late summer Aphanizomenon and Microcystis populations in a shallow lake, Müggelsee, Berlin, Germany. In TUNDISI, JG. and STRASKRABA, M., eds. Theoretical Reservoir Ecology and its Applications. Leiden: Brazilian Academy of Sciences, International Institute of Ecology and Backhuys Publishers. p. 411- 423.

PINTO-COELHO, RM., AZEVEDO, LM. DE A., RIZZI, PEV., BEZERRA-NETO, JF. and ROLLA, ME. 2005. Origens e efeitos do aporte externo de nutrientes em um reservatório tropical de grande porte: reservatório de São Simão (MG/GO). In NOGUEIRA, MG., HENRY, R. and JORCIN, A., eds. Ecologias de reservatórios: impactos potenciais, açôes de manejo e sistema em cascata. Rima: São Carlos. cap. 05, p. 127-164.

RAIJ, BV., CANTARELLA, H., QUAGGIO, JA. and FURLANI, AMC. 1996. Recomendaçôes de adubação e calagem para o Estado de Sáo Paulo. 2nd ed. Campinas: Instituto Agronômico. $39 \mathrm{p}$.

REYNOLDS, CS. 1984. The Ecology of Freshwater Phytoplankton. Cambridge: Cambridge University Press. $384 \mathrm{p}$.

REYNOLDS, CS. 1992. Eutrophication and the management of planktonic algae: What Vollenweider couldn't tell us. In SUTCIFFE, DW. and JONES, JG., eds. Eutrophication: research and application to water supply. Ambleside: Freshwater Biological Association Publication.

REYNOLDS, CS. 1996. The plant life of the pelagic. Verhandlungen des Internationalen Verein Limnologie, vol. 26, p. 97-113.

REYNOLDS, CS. 1999. Phytoplankton assemblages in reservoirs. In TUNDISI, JG. and STRASKRABA, M., eds. Theoretical reservoir ecology and its applications. São Carlos. p. 439-456.

ROSA, ZM., TORGAN, LC., LOBO, EA. and HERZOG, LAW. 1988. Análise da estrutura de comunidades fitoplanctônicas e de algun fatores abióticos em trecho do Rio Jacuí, Rio Grande do Sul, Brasil. Acta Botanica Brasilica, vol. 2, no. 1-2, p. 31-46. http://dx.doi.org/10.1590/S010233061988000100003

ROSÉN, G. 1981. Phytoplankton indicators and their relations to certain chemical and physical factors. Limnologica, vol. 13, p. 263-290.

SANTOS, ACA. and CALIJURI, MC. 1998. Survival strategies of some species of the phytoplankton community in the Barra Bonita Reservoir (São Paulo, 
Brazil). Hydrobiologia, vol. 367, p. 139-152. http:// dx.doi.org/10.1023/A:1003276016149

SANTOS, MJ. and ROCHA, O. 1998. Plankton community structure and its relation to the water quality is streams under urban impacts. Algological Studies, vol. 26, p. 1266-1270.

SOMMER, U. 1984. The paradox of the plankton: flutuations os phosphorus availability maintain diversity of phytoplankton in flow-through cultures. Limnology and Oceanography, vol. 29, no. 3, p. 633-636 http://dx.doi.org/10.4319/ lo.1984.29.3.0633

SOMMER, U. 1988. Growth and survival strategies of plankton succession. In SOMMER, U., ed. Plankton Ecology - Succession in Plankton Communities. Springer Series in Contemporary Bioscience. p. 57-106.

StatSoft. 2001. Statistica (data analysis software system). version 6. (software). Tulsa: Statsoft Inc.

STRICKLAND, JD. and PARSONS, TR. 1960. A manual of sea water analysis. Bulletin of the Fisheries Research Board of Canada, vol. 125, p. 1-185.
TALLING, JF. and DRIVER, D. 1963. Some problems in the estimation of chlorophyll $a$ in phytoplankton. In Proceedings of the Conference of Primary Productivity Measurements in Marine and Freshwater, 1961. Hawaii: USAEE. p. 142-146.

TRAIN, S. and RODRIGUES, LC. 1998. Temporal fluctuations of the phytoplankton community of the Baía River, in the upper Paraná River floodplain, Mato Grosso do Sul, Brazil. Hidrobiologia, vol. 361, p. 125-134 http://dx.doi. org/10.1023/A:1003118200157

UTHERMÖHL, H. 1958. On the perfecting of quantitative phytoplankton method. International Association of Theoretical and Applied Limnology Commun, vol. 9, p. 38.

VINCENT, WF. and DRYDEN, SJ. 1989. Phytoplankton succession and cyanobacterial dominance in a eutrophic lake of the mid-temperate zone (Lake Okaro, New Zealand). In VINCENT, WF., ed. Cyanobacterial growth and dominance in two eutrophic lakes. Schweizerbart'sche Verlagsbuchhandlung. p. 137-163.

Received: 11 January 2012 Accepted: 31 May 2012 